\title{
Multiple Disadvantages: An Empirical Test of Intersectionality Theory in EEO Litigation
}

\author{
Rachel Kahn Best \\ Lauren B. Edelman \\ Linda Hamilton Krieger \\ Scott R. Eliason
}

\begin{abstract}
A rich theoretical literature describes the disadvantages facing plaintiffs who suffer multiple, or intersecting, axes of discrimination. This article extends extant literature by distinguishing two forms of intersectionality: demographic intersectionality, in which overlapping demographic characteristics produce disadvantages that are more than the sum of their parts, and claim intersectionality, in which plaintiffs who allege discrimination on the basis of intersecting ascriptive characteristics (e.g., race and sex) are unlikely to win their cases. To date, there has been virtually no empirical research on the effects of either type of intersectionality on litigation outcomes. This article addresses that lacuna with an empirical analysis of a representative sample of judicial opinions in equal employment opportunity (EEO) cases in the U.S. federal courts from 1965 through 1999. Using generalized ordered logistic regression and controlling for numerous variables, we find that both intersectional demographic characteristics and legal claims are associated with dramatically reduced odds of plaintiff victory. Strikingly, plaintiffs who make intersectional claims are only half as likely to win their cases as plaintiffs who allege a single basis of discrimination. Our findings support and elaborate predictions about the sociolegal effects of intersectionality.
\end{abstract}

$\mathrm{T}$

wenty years ago, Kimberlé Crenshaw introduced the idea that civil rights laws are ill equipped to address the types of inequality and discrimination faced by people who suffer multiple, or "intersecting," axes of discrimination (Crenshaw 1989). Her work has inspired two decades of research on intersectionality in many fields, including critical race theory, stratification, social psychology, and

We thank the National Science Foundation (SES 0651870), the University of California Committee on Research, the UC Berkeley School of Law, and the Berkeley Empirical Legal Studies Fellowship for providing funds for data collection and analysis. We also thank the participants in the Berkeley Sociology Department's Race Workshop and the Center for the Study of Law and Society Speaker Series for discussions that influenced many of the ideas in this article. In addition, we would like to thank Catherine Albiston, Hana Brown, Lani Guinier, Mike Hout, Laura Mangels, Joy Milligan, Calvin Morrill, Sandra Smith, and three anonymous reviewers for extremely helpful comments on earlier versions of this article. Please address correspondence to Rachel Best, Department of Sociology, University of California, Berkeley, 410 Barrows Hall, Berkeley, CA 94720; e-mail: rbest@berkeley.edu.

Law E Society Review, Volume 45, Number 4 (2011)

(C) 2011 Law and Society Association. All rights reserved. 
women's studies. Yet despite the richness of the theoretical scholarship on the legal disadvantages confronted by women of color, there has been virtually no empirical research that addresses the effects of intersectionality on litigation outcomes.

This article addresses that lacuna by examining the effects of intersectional demographic characteristics and intersectional legal claims on plaintiffs' likelihood of success in discrimination lawsuits. Using a representative sample of judicial opinions over 35 years of federal employment discrimination litigation, we show that nonwhite women are less likely to win their cases than is any other demographic group. Additionally, plaintiffs who make intersectional claims, alleging that they were discriminated against based on more than one ascriptive characteristic, are only half as likely to win their cases as are other plaintiffs. Our results suggest that antidiscrimination lawsuits provide the least protection for those who already suffer multiple social disadvantages, thus limiting the capacity of civil rights law to produce social change.

\section{Limitations of Civil Rights Law}

Federal equal employment opportunity (EEO) laws attempt to prevent and redress discrimination in employment, a major source of economic and social inequality. A growing body of literature analyzes the capacity and limitations of EEO law to ameliorate inequality in the workplace. EEO law has, to some extent, improved women's and nonwhites' position in the labor market and workforce (Beller 1982; Burstein \& Edwards 1994; Eberts \& Stone 1985; Heckman \& Verkerke 1990; Leonard 1984, 1986; Skaggs 2008, 2009). However, a large body of legal and sociolegal literature highlights the many limitations of civil rights law in redressing inequalities at work. Some limitations stem from power disparities in litigation. Sociologists of law point out that the rightsmobilization process, in which victims must generally perceive rights violations and endure the prolonged and costly process of litigation in order to realize the benefits of legal rights, tends to penalize precisely those who rights are intended to benefit: individuals with fewer social, economic, and political resources (Albiston 1999, 2005; Bumiller 1987, 1988; Felstiner et al. 1980/1981; Galanter 1974; Marshall 2005; Miller \& Sarat 1980; Nielsen 2004a, 2004b; Nielsen et al. 2010; Scheingold 1974). A second set of limitations of EEO law's potential to redress inequalities stems from mismatches between discrimination as conceptualized by law and discrimination as experienced in the workplace. EEO law generally conceptualizes discrimination as intentional, disregards its structural forms, and fails to recognize how employment practices sustain patterns of market-based discrimination (Haney Lopez 
2000; Krieger 1995; Nelson \& Bridges 1999; Schultz 1990; Schultz \& Petterson 1992; Sturm 2001; Sturm \& Guinier 1996). Additionally, courts may help to institutionalize ineffective organizational responses to law by deferring to compliance structures that symbolize attention to law but are ineffective at combating discrimination (Edelman 2005, 2007; Edelman et al. 1999, 2011 ; Kalev et al. 2006).

In this article, we turn our attention to a stumbling block for EEO law that has received much attention in critical race and feminist scholarship but relatively little attention in empirical analyses of inequality in the courts: intersectionality. As described below, intersectionality disadvantages plaintiffs both as a source of inequality in litigation and as a mismatch between legal conceptualizations and actual experiences of discrimination.

Twenty years of work by sociolegal scholars suggests that plaintiffs who face multiple disadvantages fare less well in civil rights litigation than do plaintiffs who suffer a single form of social disadvantage (Austin 1989; Caldwell 1991; Carbado \& Gulati 2001; Crenshaw 1989, 1991, 1992; Harris 1997; Roberts 1991; Smith 1991; Wei 1996; Williams 1991). The key insight of intersectionality theory is that discrimination and disadvantage are not just additive; categories may intersect to produce unique forms of disadvantage. For example, an employer might hire both white women and black men but refuse to hire black women because he stereotypes them as desperate single mothers (Kennelly 1999); since this stereotype is specific to black women, it cannot be explained as the summed effects of racism and sexism. ${ }^{1}$

Intersectionality theorists have suggested two distinct processes through which people facing multiple disadvantages are subordinated in the courts, but have not explicitly distinguished between these types, causing some confusion. To highlight the fact that intersectional disadvantages comprise two distinct mechanisms of subordination, we formulate and investigate two different constructs: demographic intersectionality, in which the courts are the site of intersectional disadvantages or discrimination, and claim intersectionality, in which the law does not adequately redress intersectional discrimination that occurs in the labor market. Demographic intersectionality can be thought of as a type of inequality in litigation, while claim intersectionality can be thought of as a mismatch between discrimination as conceptualized by law and discrimination as experienced in the labor market.

${ }^{1}$ Although the concept of intersectionality can apply to any intersecting ascriptive characteristics, the bulk of the literature focuses on black women. Here, we use black women as the prototypical example, keeping in mind that the concept applies to other groups as well. 


\section{Demographic Intersectionality}

Demographic intersectionality disadvantages occur when discrimination and/or stereotyping targets plaintiffs who occupy the intersection of two or more demographic categories. For these plaintiffs, overlapping axes of disadvantage may add up to more than the sum of their parts. Articulating the mechanisms through which intersectional stereotypes operate, social psychologists find that people sometimes merge information from multiple categories to create subcategories with attendant stereotypes (Bodenhausen 2010; Roccas \& Brewer 2002), and that information about characteristics or roles can take on new meanings when nested within other categorical formations (Hutter \& Crisp 2005; Kunda \& Thagard 1996; Richards \& Hewstone 2001; Ridgeway 1997; Stangor et al. 1992). By demonstrating that status characteristics are not always perceived independently, this experimental research suggests that intersectional stereotypes are likely to emerge and to influence social perception and judgment.

Indeed, recent empirical research on hiring and discrimination provides evidence that employers hold discrete stereotypes for various intersectional categories. Employers may stereotype innercity blacks (but not necessarily other blacks or white inner-city residents) as lazy and dangerous (Kirschenman \& Neckerman 1991; Moss \& Tilly 2001). Employers also hold different stereotypes about black men and black women. They sometimes stereotype black women negatively as desperate single mothers (Kennelly 1999) or positively as responsible "matriarchs" (Shih 2002: 111). Black men, on the other hand, are stereotyped as "unmanageable workers [who are] more likely to resist authority" (Shih 2002: 102). Using census data, Kaufman (2002) concludes that employers often have preconceived notions about which race and sex combinations are right for a job and tend to select job applicants who match these stereotypes. Interview-based research and audit studies confirm that employers prefer to hire white men for low-skilled jobs (Moss \& Tilly 2001; Turner et al. 1991).

Judges, juries, and lawyers are subject to the same institutionalized stereotypes as are employers. If they introduce these stereotypes into legal decisionmaking, the types of stereotypes discussed in the literature on labor-market discrimination may also affect court outcomes, with courts replicating the discriminatory practices that operate in the labor market.

\section{Claim Intersectionality}

Claim intersectionality is present when plaintiffs allege discrimination on the basis of two or more ascriptive characteristics. Critical race theorists have argued that since antidiscrimination law organ- 
izes demographic traits into formal, one-dimensional categoriesrace, sex, national origin, and so forth-legal doctrine often fails to capture the types of discrimination suffered by intersectional subjects (Austin 1989; Caldwell 1991; Crenshaw 1989; Harris 1990; Roberts 1991). So, for example, sex discrimination is conceptualized in antidiscrimination case law as a problem affecting all women equally and in the same ways (with white women as the prototypic case), while race discrimination is understood as affecting all blacks (prototypically male) in the same ways (Crenshaw 1989; Harris 1990). Intersectionality theorists argue that this one-dimensional, categorical approach to understanding discrimination prevents civil rights law from adequately protecting members of groups that experience more than one axis of prejudice.

For example, an employer might be willing to hire black men and white women as retail salespeople but unwilling to hire black women because he thinks that customers will stereotype them in disparaging ways that will harm his business (Smith 1991: 28). Or, as another example, an employer might fire a black female employee because the employer is discomfited by her Afrocentric feminine attire or hairstyle (Caldwell 1991). Their employees might make what we call intersectional claims: allegations that they were discriminated against due to more than one ascriptive characteristic. But since these types of discrimination would not affect minority men or white women, under some interpretations of EEO law, the employer could parry a claim of race discrimination by pointing to the hiring of men belonging to the plaintiff's racial group and deflect a claim of sex discrimination by pointing to his hiring of white women (Crenshaw 1989; Harris 1990; Smith 1991).

Thus, plaintiffs who make intersectional discrimination claims may be less likely to win their cases not only because they are members of particularly derogated subgroups, but also because, given the categorical nature of discrimination law, intersectional claims are particularly hard to establish. While demographic intersectionality can produce unequal outcomes in all arenas of social life, claim intersectionality is a mechanism of disadvantage that is particular to civil rights litigation.

\section{Lack of Empirical Research on Intersectionality and Litigation Outcomes}

Although a substantial and rich literature describes the nature of intersectionality and demonstrates how intersectionality has penalized plaintiffs in particular cases, there has been no systematic effort to determine the extent to which intersectionality penalizes plaintiffs in litigation generally. Regarding demographic intersectionality, some studies have compared litigation outcomes across 
gender or racial groups, but most studies have examined race and gender disparities separately, comparing all men to all women or comparing all racial minorities to all whites (Babcock 1993; Nelson 1994; Resnik 1991; Schafran 1998; Selby 1999). Since they ignore the intersection of race and gender, these studies may elide important differences among subgroups, and we remain in the dark about whether race disparities are constant across gender, and vice versa. One exception to this trend is Oppenheimer (2003), who examined a sample of 334 employment-discrimination and wrongful-discharge cases tried in the California state courts and found that black women had low win rates in cases alleging sex discrimination or race discrimination. While these results suggest that plaintiffs with intersecting disadvantaged statuses may fare worse in the California state courts, the study did not test whether the differences were statistically significant or control for other characteristics of the cases. To fully examine demographic intersectionality, we must statistically compare outcomes for white men, white women, nonwhite men, and nonwhite women.

Claim intersectionality has attracted more scholarly attention in the form of several qualitative analyses of employment discrimination opinions by critical race theorists (Crenshaw 1989; Cunningham 1998; Scales-Trent 1989; Smith 1991). This work highlights a series of judicial opinions with widely varying treatment of intersectional claims. In some cases, judges have not recognized intersectional claims as being legally cognizable and have dismissed them at the outset. Crenshaw's (1989) foundational article on intersectionality, for example, centers on the case of DeGraffenreid $v$. General Motors (1976), in which the plaintiffs established that GM had not hired any black female workers before 1964 and that all the black women hired after 1970 had lost their jobs in a later senioritybased layoff. The court ruled that black women were not a protected class under Title VII. Since the company had hired white women, no sex discrimination had occurred. Since the company had hired black men, no race discrimination had occurred either. A similar fate befell black female plaintiffs in Jewel C. Rich v. Martin Marietta (1975), Ella Logan v. St. Luke's Hospital Center (1977), and Mary M. Love v. Alamance County Board of Education (1984), where the judges also considered race and sex claims separately and disregarded statistical evidence of discrimination against black women as legally irrelevant. ${ }^{2}$

2 In these cases, black female plaintiffs alleging race and sex discrimination were at a disadvantage because the courts considered each type of discrimination separately. Crenshaw (1989) describes another pattern of rulings in which black women were not allowed to represent all women or all blacks in class-action lawsuits. Our data do not allow us to observe the latter pattern; our measure of claim intersectionality focuses only on the former. 
However, in other opinions, the courts have been sympathetic to intersectional claims. In Jefferies v. Harris County Community Action Association (1980), the court ruled that "discrimination against black females can exist even in the absence of discrimination against black men or white women" (quoted in Scales-Trent 1989: 17). Similarly, in reversing the district court's grant of summary judgment in Lam $v$. University of Hawai"i (1994), the U.S. Court of Appeals for the Ninth Circuit criticized the district court for imagining that racism and sexism can be evaluated separately. Finally, some opinions are mixed. In Judge v. Marsh (1986), the court stated that it would consider intersections of two characteristics but not three or more, out of the concern that considering too many intersections would turn Title VII into a "many-headed Hydra" and make it impossible to make any employment decisions "without incurring a volley of discrimination charges" (quoted in Scales-Trent 1989: 37).

These cases reveal the courts' varying responses to intersectional claims but leave broader patterns obscure: How many plaintiffs are bringing intersectional claims? On the whole, are plaintiffs who bring intersectional claims less likely to win their cases? And if so, can any other characteristics of the cases explain this disadvantage? These questions can best be addressed through quantitative empirical research. However, to date, there has been very little empirical research on the effects of claim intersectionality on litigation outcomes. To our knowledge only one preliminary empirical analysis speaks directly to this question. Kotkin (2009) examined 26 employment discrimination summary judgment adjudications in the federal district courts for the Southern and Eastern Districts of New York in which plaintiffs presented multiple-basis claims. These plaintiffs lost the defense motion for summary judgment 96 percent of the time, which is higher than plaintiff loss rates reported by other studies of summary judgment outcomes, providing suggestive evidence that plaintiffs alleging multiple bases of discrimination fare poorly. However, the study did not include a comparison group of single-basis claims, thus leaving it unclear whether plaintiffs alleging single bases of discrimination fared better, and if so, whether the differences were statistically significant. Documenting claim-intersectionality disadvantages requires systematically testing whether intersectional claims fare worse than other claims do.

Thus, no existing research systematically compares intersectional and nonintersectional cases and tests whether intersectional cases fare significantly worse. Our analysis addresses the lacuna of empirical data and findings on this issue by investigating intersectionality disadvantages using a probability sample of federal civil rights opinions. 


\section{The Politics of Methods in Intersectionality Scholarship}

The lack of quantitative empirical work on intersectionality is due in part to methodological conflicts within critical race scholarship. The first point of controversy centers on how to use categories in research on intersectionality. Scholars who believe that the main contribution of intersectionality theory is the documentation of the detrimental effects of categorization are loath to use their own work to divide people in to categories. Additionally, some scholars suggest that intersectionality cannot be captured through an interaction effect because the social construction of categories is contingent and fluid (Collins 1990; King 1988; West \& Fenstermaker 1995). However, other researchers defend the importance of using categories to document inequalities (McCall 2001, 2005). ${ }^{3}$

The second point of disagreement centers on research methods. Critical race scholars who study intersectionality use almost exclusively qualitative and interpretive methods (Abrams 1994; Austin 1989; Caldwell 1991; Crenshaw 1989, 1991, 1992; Delgado 1995; Roberts 1991; Smith 1991; Williams 1991). Many critical race scholars criticize quantitative research as overly simplistic and positivist (Davis 2008; McCall 2005). However, a smaller group of researchers criticizes the exclusive use of qualitative methods for providing inadequate documentation of inequalities (Nash 2008), argues for the use of statistics to document differing outcomes among groups (Baldus et al. 1990; McCall 2005), and calls for greater dialogue between critical race theory and empirical research on law and society (Gomez 2004).

We argue that these conflicts can be resolved by recognizing that the best method of analysis depends on the nature of the research question and the dependent variable. While qualitative research is most appropriate for in-depth studies of experiences and identities (Harvey 2005; Hondagneu-Sotelo 2001), quantitative research may be best suited to documenting the aggregate patterns that constitute between-group inequalities (McCall 2001, 2005; Yuval-Davis 2006). While racial, sex, or other categories certainly do not richly describe people's experiences and identities, differing outcomes across these categories are important indicators of structural inequality and social stratification. Additionally, as the social categories on which discrimination is often based and through which legal claims must be pursued, these categories have real effects.

While there is an extensive research literature exploring intersectional experiences and identities, researchers have rarely sought to document the effects of intersectionality on inequality (Browne \&

${ }^{3}$ Some researchers also find a middle ground between deconstructing categories and adopting them completely (McCall 2005). 
Misra 2003). Attributing this neglect to methodological preferences, McCall argues that suspicion of statistics has "restrict[ed] the scope of knowledge that can be produced on intersectionality" (McCall 2005: 1772). This neglect is so extreme that the hypothesis that Crenshaw (1989) introduces in her foundational article on intersectionality-that intersectional plaintiffs fare worse in discrimination lawsuits-has not been systematically tested. Our study is designed to test this hypothesis.

\section{Methods}

\section{Sample}

Our study draws upon a representative sample of judicial opinions in EEO cases, allowing us to provide generalizable findings on patterns in EEO decisions. We first retrieved all federal employment opinions decided by the U.S. district and circuit courts between 1965 and 1999 and available in the Westlaw database, which yielded a sampling frame of over 50,000 opinions. ${ }^{4}$ We then selected a 2 percent random sample, yielding 328 circuit court opinions and 686 district court opinions. ${ }^{5}$

Our sample is unique in its inclusion of opinions from both the district and the circuit courts. The few previous empirical studies of civil rights judicial opinions focus only on the Supreme Court and federal circuit courts (Burstein \& Edwards 1994; Burstein \& Monaghan 1986). While appellate opinions establish precedent and therefore become the "leading cases," the district courts handle many more cases, making them the primary federal locale for civil rights dispute resolution. Thus, including the district courts provides important information on civil rights conflict resolution where it more frequently occurs. ${ }^{6}$

It is important to note that while our sample is representative of judicial opinions, it is not representative of all instances of discrimi-

4 Since Lexis and Westlaw include many of the same opinions, we sample only from the Westlaw database to avoid duplication. We used a broad search term in order to include all federal civil rights decisions issued under Title VII of the Civil Rights Act of 1964, the Age Discrimination in Employment Act of 1967, the Equal Pay Act of 1963, two post-Civil War Civil Rights Acts, and 42 U.S.C. Sections 1981 and 1983.

${ }^{5}$ Once the initial sample was selected, we read each opinion and rejected those that (a) were not principally about civil rights, (b) did not involve adjudication on the merits of the case, or (c) arose from an appeal of a decision by the Merit Systems Protection Board. Rejected cases were replaced with the next case in chronological order. For this analysis, we also dropped 10 cases with missing data.

${ }^{6}$ We did not include Supreme Court cases because they are few in number and we wanted to examine the impact of major Supreme Court decisions on our dependent variables. 
nation or charges filed. ${ }^{7}$ Large-scale surveys tell the story of a "dispute pyramid" (Miller \& Sarat 1980) in which judicial opinions reflect only the tip of the iceberg. Only 5 percent of perceived instances of employment discrimination evolve into court filings (Miller \& Sarat 1980), and almost 60 percent of employment discrimination cases filed in federal court settle (Nielsen et al. 2010). ${ }^{8}$ Intersectional plaintiffs may well be disadvantaged at all stages of the dispute pyramid, but since our focus is on plaintiffs' likelihood of success when their cases reach a judge, we do not include these earlier stages in our study.

\section{Coding}

We coded each opinion for court (which circuit or which district), judges, plaintiff characteristics, defendant characteristics, statutory claims involved in the case, challenged actions, legal theories on which the claims were based, which party prevailed (and the extent to which they prevailed), and a variety of other variables. Table 1 presents descriptive statistics for the variables used in the analysis. Given the complexity of our coding scheme, we took numerous measures to ensure intercoder reliability. We developed and refined the coding scheme through an iterative procedure involving trial coding of opinions by five researchers over a period of about one year and then ran a series of reliability checks to ensure that there were no systematic differences among the coders. $^{9}$

\section{Dependent Variable: Who Wins}

Our dependent variable is who wins the case. This variable has three categories: employer wins $(\mathrm{N}=595)$, mixed outcomes in

${ }^{7}$ Siegelman and Donohue (1990) note that the cases available in online databases are a biased sample of cases filed. However, most of this bias is due to the fact that most cases drop out before requiring a judicial decision, usually due to settlement. Westlaw attempts to include every federal decision, including those that are not legally "published," increasing the extent to which our sample is representative of all judicial opinions.

${ }^{8}$ Some cases result in judicial opinions before eventually settling (e.g., a case that survived a motion to dismiss or a motion for summary judgment and later was settled). Other settled cases never result in judicial opinions and so would not be included in our sample.

${ }^{9}$ Each week, five researchers independently coded five opinions, discussed discrepancies, and refined the coding scheme. This process was repeated until the five researchers reached agreement percentages of approximately 90 percent for all codes. One of the researchers then completed all of the circuit court coding. Next, district court coders, all of whom had completed a course in EEO law, underwent 100 hours of coding training. They began actual coding once their agreement percentages with previous codes consistently exceeded 80 percent. Finally, 5 percent of the district court opinions were randomly selected and recoded, and reliability checks showed no systematic discrepancies and over 90 percent agreement. 
Table 1. Descriptive Statistics

\begin{tabular}{|c|c|c|}
\hline & Percent & Mean (SD) \\
\hline \multicolumn{3}{|l|}{ Case outcome (dependent variable) } \\
\hline Employer wins & $58 \%$ & \\
\hline Mixed outcome & $15 \%$ & \\
\hline Employee wins & $27 \%$ & \\
\hline \multicolumn{3}{|l|}{ Type of claim } \\
\hline Intersectional claims ${ }^{1}$ & $18 \%$ & \\
\hline Multiple nonintersectional claims ${ }^{2}$ & $25 \%$ & \\
\hline Single claims & $58 \%$ & \\
\hline \multicolumn{3}{|l|}{ Demographics } \\
\hline White men & $4 \%$ & \\
\hline White women & $2 \%$ & \\
\hline Nonwhite men & $19 \%$ & \\
\hline Nonwhite women & $11 \%$ & \\
\hline Race missing & $60 \%$ & \\
\hline Sex missing & $10 \%$ & \\
\hline \multicolumn{3}{|l|}{ Mediating variables } \\
\hline Section 1981 and Title VII claims & $19 \%$ & \\
\hline Section 1981 and Title VII $\mathrm{x}$ intersectional claim & $6 \%$ & \\
\hline Judicial deference to employer's structures & $27 \%$ & \\
\hline \multicolumn{3}{|l|}{ Resources } \\
\hline Plaintiff is a union member & $17 \%$ & \\
\hline $\begin{array}{l}\text { Government or public-interest lawyer representation of } \\
\text { or amicus for plaintiff }\end{array}$ & $9 \%$ & \\
\hline Plaintiff's occupational prestige (missing set to mean) & & $47(12.8)$ \\
\hline Prestige missing & $21 \%$ & \\
\hline \multicolumn{3}{|l|}{ Motion/procedural posture } \\
\hline Motion to dismiss & $5 \%$ & \\
\hline Employer's motion for summary judgment & $51 \%$ & \\
\hline \multicolumn{3}{|l|}{ Other control variables } \\
\hline Number of challenged employer actions ${ }^{3}$ & & $1.69(.98)$ \\
\hline Circuit court $($ circuit court $=1$, district court $=0$ ) & $32 \%$ & \\
\hline Published case & $56 \%$ & \\
\hline Length of opinion (pages) & & $6.92(6.77)$ \\
\hline Post-1986 & $71 \%$ & \\
\hline
\end{tabular}

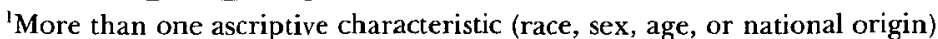

${ }^{2}$ E.g., race and retaliation

${ }^{3}$ E.g., hiring, termination, compensation

which both parties win something on the principle $(\mathrm{N}=147)$, and employee wins $(\mathrm{N}=280) .{ }^{10}$ In all analyses, we first examine plaintiffs' odds of achieving at least a partial victory and then move on to measure plaintiffs' odds of a complete victory.

\section{Independent Variables}

\section{Claim Intersectionality}

Claim-intersectionality theory suggests that plaintiffs are at a disadvantage when they allege intersectional discrimination,

${ }^{10}$ We code mixed outcomes where the employer won on the principle $(\mathrm{N}=5)$ as employer victories, and mixed outcomes where the employee won on the principle $(N=48)$ as employee victories. 
Table 2. Number of Sampled Cases with Various Bases of Discrimination

\begin{tabular}{lc}
\hline Bases of \\
Discrimination Alleged & $\begin{array}{c}\text { Number of Cases } \\
\text { (Percent of Sample) }\end{array}$ \\
\hline Race and sex & $60(6 \%)$ \\
Race and age & $21(2 \%)$ \\
Race and national origin & $29(3 \%)$ \\
Sex and age & $28(3 \%)$ \\
Sex and national origin & $3(<1 \%)$ \\
Age and national origin & $9(1 \%)$ \\
Three- and four-way intersections & $28(3 \%)$ \\
Total & $178(18 \%)$ \\
\hline
\end{tabular}

regardless of their demographic characteristics. We observe claim intersectionality when a plaintiff alleges discrimination based on more than one of the following ascriptive characteristics: race, sex, age, or national origin. ${ }^{11}$ Table 2 presents descriptive statistics for the specific intersections in our sample. The intersection of race and sex accounted for one-third of intersectional claims, and race and age, race and national origin, sex and age, and three- and four-way intersections also appeared relatively frequently.

Instead of using an interaction effect, as we do to measure demographic intersectionality (see below), we measure claim intersectionality using three mutually exclusive dummy variables. We distinguish intersectional claims from cases where plaintiffs allege only one basis of discrimination and also from cases where plaintiffs allege multiple nonintersectional bases of discrimination (that is, more than one basis of discrimination of which only one or none are ascriptive characteristics). For instance, a case with allegations of race and sex discrimination is coded as intersectional, while a case with allegations of race discrimination and retaliation is not. By this definition, 18 percent of cases in our sample make intersectional claims (see Table 1 ). ${ }^{12}$

\section{Demographic Intersectionality}

Demographic intersectionality theory yields the hypothesis that various axes of disadvantage (race, sex, age, sexuality, and so on) do not operate independently in the courts. All our data on plaintiffs' demographics are coded from judicial opinions, which rarely

"The bases of discrimination that we do not call ascriptive characteristics are retaliation, religion, disability, family and medical leave, and pregnancy.

${ }^{12}$ Some allegations of discrimination based on multiple ascriptive characteristics make explicitly intersectional claims (e.g., that an employer hires black men and white wornen but refuses to hire black women), while others make tacitly intersectional claims (e.g., that an employer refuses to hire black women). We categorize both types of cases as making intersectional claims because intersectionality theory suggests that both should result in a reduced likelihood of plaintiff success. 
mention demographic characteristics other than race or sex. Thus, although demographic intersectionality theory could apply to the intersection of any demographic characteristics, we can only test it for the intersection of race and sex. Our data are further limited by the fact that the plaintiffs' race and sex are not always mentioned in the judicial opinions. In 40 opinions, we could not determine the plaintiffs' sex. Additionally, 57 cases involved a mixed-sex group of plaintiffs or an organizational plaintiff. We combined these two types of cases into a "missing sex" group that makes up 9.5 percent of the sample (see Table 1). ${ }^{13}$ Our data on the plaintiffs' races are sparser. Thirty-two cases involved a racially mixed group of plaintiffs. In an additional 579 opinions, the plaintiffs' races were not mentioned. We combine racially mixed groups of plaintiffs and plaintiffs whose race was not mentioned into a "missing race" category that comprises 60 percent of our sample (see Table 1). We originally coded plaintiffs' races into six categories, ${ }^{14}$ but our sample is too small to examine each racial category separately. Therefore, we compare the 60 plaintiffs we can identify as white to the 353 plaintiffs we can identify as nonwhite, a category that includes blacks, Hispanics, Asians and Pacific Islanders, Native Americans, and plaintiffs of other nonwhite races (see Table 1). Most of the plaintiffs we can identify as nonwhite are black (84 percent). To see whether patterns differed between blacks and other minorities, we also ran our models with three racial categories and found no important differences. ${ }^{15}$

As might be expected, most opinions that mentioned the plaintiffs' races resulted from cases alleging race or national origin discrimination. Of the 353 plaintiffs we can identify as nonwhite, 320 alleged discrimination on the basis of race or national origin. We were concerned that the 33 opinions in which judges mentioned the plaintiff's race even though the plaintiff was not alleging racial or national origin discrimination might be unusual cases or might differ in some way from race and national origin cases. Therefore, we reran all analyses with interaction effects between the race variables and whether the case included race or national origin claims; our substantive results were unchanged. ${ }^{16}$

Thus, our data on plaintiffs' demographic characteristics are more limited than our data on intersectional claims: we only have

13 In four cases, the plaintiff was identified as a gender other than male or female. Since this group of cases was too small to analyze separately, we include them with the "missing gender" group for the purpose of the statistical analyses.

14 White $(N=60)$; black $(N=295)$; Hispanic $(N=31)$; Asian/Pacific Islander $(N=11)$; Native American $(\mathrm{N}=2)$; Other race $(\mathrm{N}=14)$.

15 Results available from the authors upon request.

${ }^{16}$ Results available from the authors upon request. 
Table 3. Overlap between Nonwhite Female Plaintiffs and Intersectional Claims

\begin{tabular}{lccc}
\hline & Intersectional Claim & Other Claim & Total \\
\hline Nonwhite female plaintiff & $45(42 \%)$ & $62(58 \%)$ & $918(100 \%)$ \\
Other plaintiff & $133(14 \%)$ & $785(86 \%)$ & $107(100 \%)$ \\
Total & $178(\mathbf{1 7 \%})$ & $847(83 \%)$ & \\
\hline
\end{tabular}

measures of plaintiffs' race and sex, and even that information is missing for a large proportion of plaintiffs. However, since we take care to distinguish between plaintiffs with missing and nonmissing data, we can draw some conclusions about the effects of race and sex on litigation outcomes. To test the hypothesis that race- and sex-based disadvantages do not operate independently in the courts, we ran regressions with variables for plaintiffs' race and sex and an interaction effect between race and sex. This modeling strategy distinguishes between white male, white female, nonwhite male, and nonwhite female plaintiffs, and plaintiffs with unknown race or sex.

\section{Overlap between Claim and Demographic Intersectionality}

Claim intersectionality and demographic intersectionality overlap but are not perfectly correlated. Nonwhite female plaintiffs are more likely to make intersectional claims than are other plaintiffs. However, not all nonwhite female plaintiffs make intersectional claims (for instance, a black female plaintiff might sue for race discrimination alone), and not all intersectional claims are brought by nonwhite women (for instance, a claim of race and age discrimination might be brought by a black man, or a white man might claim reverse race and sex discrimination). Table 3 shows the extent to which the categories overlap. We hypothesize that demographic and claim intersectionality are two separate processes of disadvantage: intersectional claims will be less likely to succeed, regardless of plaintiffs' demographic characteristics, and race and sex disadvantages will intersect in the courts regardless of whether plaintiffs make intersectional claims.

\section{Mediating Variables}

While we theorize that demographic and claim intersectionality can operate separately, we also test whether either one mediates the other by testing their effects on case outcome separately and then including both in the same model. Additionally, we explore several other potential mediating variables.

Smith (1991) suggests that plaintiffs may be especially unlikely to prevail when they file an intersectional claim under Title VII and a race claim under Section 1981, which applies only to race 
discrimination. When plaintiffs fail to prove race discrimination under Section 1981, judges may throw out the race portion of their Title VII claims. ${ }^{17}$ Smith argues that by mistakenly assuming that intersectional race and sex claims under Title VII can be considered separately, these judges prevent intersectional claims from getting a fair hearing. To test Smith's hypothesis that the combination of Section 1981 and Title VII is disadvantageous for plaintiffs making intersectional claims, we created a variable indicating whether the case includes claims brought under both statutes and an interaction effect between this variable and claim intersectionality.

Another potential mediating variable is judicial deference to institutionalized organizational structures. Judicial deference occurs when judges take the mere presence of organizational structures as evidence of an organization's compliance with civil rights law irrespective of whether the structures actually protect employees (Edelman et al. 1999; Edelman et al. 2011). For example, despite the fact that civil rights law neither mandates the creation of organizational grievance procedures nor specifies that these structures constitute evidence of nondiscrimination, and despite the fact that many organizational grievance procedures are ineffective at reducing discrimination (Edelman 1992; Edelman et al. 1993), courts have become increasingly likely over time to accept the presence of formal grievance procedures as evidence of nondiscrimination without evaluating their effectiveness (Bisom-Rapp 1999, 2001; Edelman et al. 1999). Given research that suggests that judges are often intuitive decision makers and that intuitions are often flawed (Guthrie et al. 2007), institutionalized organizational structures may provide a heuristic mechanism through which judges are more likely to assume fair governance when they are more skeptical of the plaintiffs or the claims. Kotkin (2009) notes that some federal judges treat plaintiffs who make intersectional claims like "the child who cried wolf" (Kotkin 2009: 1458). If judges are skeptical about the existence of intersectional discrimination, they may be predisposed to seek out signs that employers charged with intersectional discrimination are rational and nondiscriminatory. Increased likelihood of judicial deference-using structures as symbolic indicia of fair treatment instead of considering evidence as to whether they reduce discrimination-may indicate a subtle shift in judges' symbolic construction of plaintiffs and defendants. Thus, if deference mediates the effect of claim intersectionality, this would indicate that judges' subjective constructions of intersectional claims account for some of intersectional plaintiffs' disadvantage.

${ }^{17}$ For instance, in Richardson v. Steak 'N Shake, Inc. (1987), the court concluded that since a jury had ruled against the plaintiff's Section 1981 race claim, the court could consider only the sex discrimination portion of her race/sex Title VII claim (Smith 1991). 
Another set of potential mediating variables measures plaintiffs' resources. While we cannot measure all aspects of plaintiffs' resources, we coded for three variables that shed some light on resources: unionization, involvement of government or publicinterest organizations, and occupational prestige. Our first measure, unionization, is a dummy variable equal to one if the judicial opinion mentions that any of the plaintiffs were union members. Second, since government or public-interest organizations can provide a substantial legal advantage to plaintiffs, we created a dummy variable equal to one if (a) the plaintiff is a government agency or public-interest organization, (b) the plaintiff is represented by a public-interest organization, or (c) a government or public-interest organization filed an amicus brief for the plaintiff. Third, we coded for plaintiffs' occupational prestige using 1980 census occupational categories and the 1989 General Social Survey (GSS) occupational prestige scale (Nakao \& Treas 1992). ${ }^{18}$ While no single measure can capture all aspects of occupational status, we expect occupational prestige rankings to be correlated with economic and cultural resources that can help plaintiffs succeed in court. If plaintiffs with particular race and sex characteristics or plaintiffs who bring intersectional claims tend to have fewer resources, then controlling for unionization, organizational involvement, and occupational prestige should decrease the size of the intersectionality coefficients.

Crenshaw and colleagues argue that doctrinal barriers and evidentiary hurdles diminish the success rates for intersectional claims. Doctrinal barriers stem from the categorical nature of discrimination law, and evidentiary hurdles from the difficulty of proving complex claims. For example, proving that nonwhite women were less likely to be promoted requires a large enough sample of nonwhite women, white women, nonwhite men, and white men in the workplace (Kotkin 2009), making it more difficult to document intersectional discrimination than it is to document discrimination based on only one characteristic. While we cannot measure doctrinal barriers and evidentiary hurdles directly, we examine whether the opinion results from a motion to dismiss or a defendant's motion for summary judgment. In a motion to dismiss, the employer argues that there is no need to consider the facts of the case, since the plaintiff's claims are inconsistent with legal doctrine. In a motion for summary judgment, the defendant argues that the plaintiff's claims can be rejected because the plaintiff has failed to adduce evidence in discovery from which a reasonable jury could find in their favor at trial. If many intersectional cases are losing on

${ }^{18}$ Occupational prestige is missing for 20 percent of the sample. We assigned these cases the mean prestige score and included a dummy variable indicating which cases had missing prestige data. 
summary judgment instead of on considerations of the facts of the case, this could indicate that procedural barriers or evidentiary hurdles are preventing intersectional claims from succeeding.

\section{Control Variables}

We control for several variables predicted to be correlated with employee victory: whether the case is in the circuit or district court, whether the opinion is legally published, ${ }^{19}$ the length of the opinion in pages, the number of employer actions the employee is challenging, and the passage of time. ${ }^{20}$ To account for change over time, we control for whether the case was decided after 1986, when the Celotex trilogy of decisions ${ }^{21}$ made it easier to obtain summary judgment and the Meritor Savings Bank v. Vinson (1986) decision stated that employers would be more likely to prevail in some types of EEO cases if they had established certain employment structures, such as antiharassment policies and grievance procedures (Edelman et al. 2011). We also ran all models with dummy variables for each year to completely account for any time patterns; our results were substantively unchanged.

\section{Analysis}

Our dependent variable has three categories: employer victory, mixed outcome, and employee victory. Our results were extremely robust to model selection: we obtained substantively equivalent results from ordered, multinomial, and generalized ordered logistic regression. ${ }^{22}$ We selected the generalized ordered logistic regression model because its moving base category makes its coefficients

19 When judges declare that a decision is not for publication, it is in theory not relevant beyond the specific case for which it is issued and does not constitute precedent. Today, approximately 80 percent of circuit court opinions and the vast majority of district court opinions are unpublished (Gerken 2004).

${ }^{20}$ In other models, we controlled for disparate impact, disparate treatment, and hostile work environment claims. Including these variables did not affect the intersectionality coefficients, and none were statistically significant predictors of employee victory.

${ }^{21}$ In Celotex Corp. v. Catrett (1986), Matsushita Electric Industries Co., Ltd. v. Zenith Radio Corp. (1986), and Anderson v. Liberty Lobby, Inc. (1984), the Supreme Court gave federal judges more leeway to grant employers' motions for summary judgment. After the Celotex cases, as Second Circuit judge Patricia Wald observed, summary judgment evolved from being a limited device to eliminate patently frivolous claims to "something more like a gestalt verdict based on an early snapshot of the case" (Wald 1998: 1917).

${ }_{22}$ We initially ran our models using ordered logistic regression, which produces parsimonious results by assuming that all coefficients are identical across all levels of the dependent variable (Long 1997). We tested this assumption using Stata's omodel and brant commands (Brant 1990; Wolfe \& Gould 1998). Both results were statistically significant $\left(\chi^{2}(12)=70.8\right.$ and 74.8 , respectively; $p<0.000$ ), indicating that the ordered logit model does not fit our data. We then considered multinomial logistic and generalized ordered logistic regression models, which had similar log likelihoods and produced substantively equivalent results (results available from the authors upon request). 
more intuitively interpretable than are the coefficients from multinomial logistic regression. In each model, the first column of coefficients refers to the plaintiff's odds of achieving at least a partial victory, while the second column refers to the plaintiff's odds of a complete victory.

\section{Results}

\section{The Increasing Prevalence of Intersectional Claims}

Intersectional claims have increased dramatically over time. In the 1970s and 1980s, less than 10 percent of EEO opinions dealt with intersectional claims. As shown in Figure 1, the proportion began rising around 1990, and by the second half of the decade, more than a quarter of EEO opinions involved intersectional claims. ${ }^{23}$ The proportion dropped somewhat in 1999, but since this is the last year we observe, we cannot discern whether this was a change in the trend or a temporary aberration. Since the total number of EEO opinions rose dramatically during this time period, the increasing proportion of intersectional claims indicates an even more dramatic increase in real numbers: we estimate that there were fewer than 100 intersectional cases per year in the district and

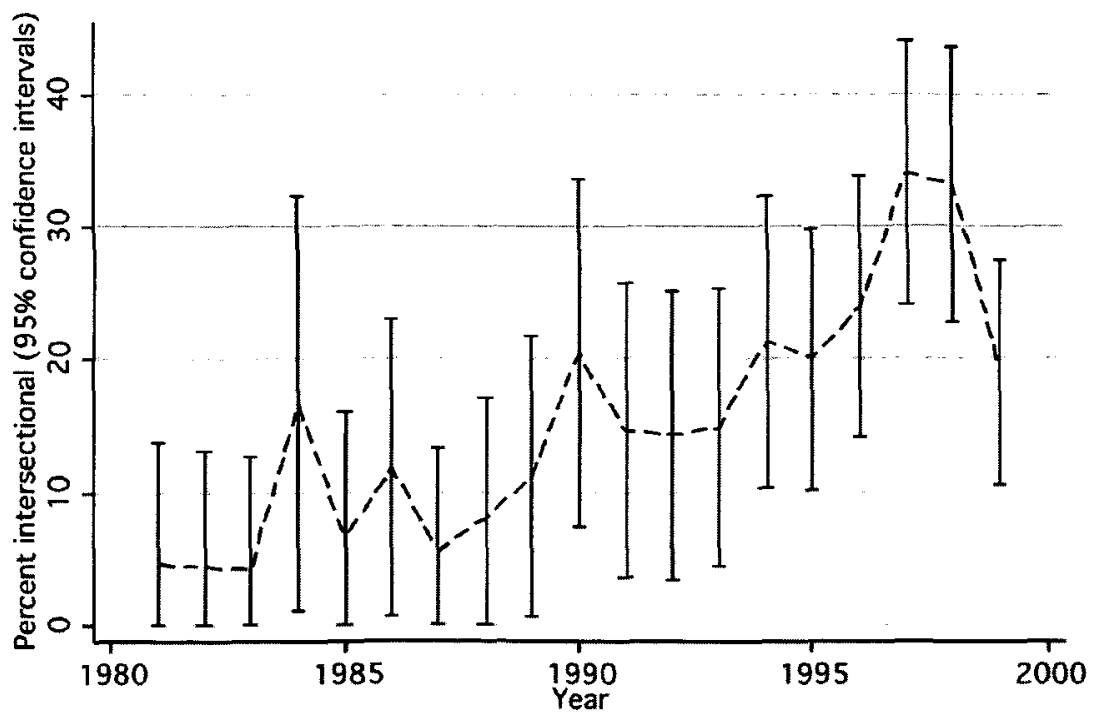

Figure 1. Percent of EEO cases with intersectional claims.

${ }^{23}$ Figure 1 begins in 1980 because of small sample sizes in the 1970s. The pooled proportions from the 1970 s are equivalent to those in the 1980 s. 
circuit courts in the 1970 s and 1980 s and over 1,000 per year by the second half of the $1990 \mathrm{~s}$. This increasing prevalence highlights the importance of learning how these claims are faring.

\section{Both Demographic and Claim Intersectionality Disadvantage Plaintiffs}

Bivariate relationships between both claim and demographic intersectionality and case outcomes yield strong support for intersectionality theory. First, plaintiffs making intersectional claims are less than half as likely to win their cases as are other plaintiffs (15 percent compared to 31 percent; see Table 4). Second, race and sex disadvantages do not operate independently. White male plaintiffs were more likely to lose their cases than white women were (61 percent as compared to 55 percent; see Table 4). This female advantage, however, does not apply to black women, who are slightly more likely than black men to lose their cases ( 71 percent as compared to 69 percent; see Table 4$).{ }^{24}$

The bivariate relationships between both types of intersectionality and employee victory provide suggestive evidence of an intersectionality penalty. Next, we conducted generalized ordered logistic regressions to control for other features of cases that might account for the relationships (see Table 5). In each model we present, the first column of coefficients denotes each variable's effects on the odds that the plaintiff will achieve at least a partial victory (a mixed outcome or a complete victory), and the second column of coefficients focuses on the odds of a complete victory.

Model 1 (Table 5) shows the effects of claim intersectionality on the likelihood of employee victory. Even when controlling for

Table 4. Case Outcome by Claim and Demographic Intersectionality

\begin{tabular}{lllr}
\hline & \multicolumn{3}{c}{ Victor: } \\
\cline { 2 - 4 } & Employer & Mixed & Employee \\
\hline Claim intersectionality & & & \\
$\quad$ Intersectional bases of discrimination $(\mathrm{N}=178)$ & $69 \%$ & $16 \%$ & $15 \%$ \\
$\quad$ Nonintersectional bases of discrimination $(\mathrm{N}=836)$ & $56 \%$ & $14 \%$ & $30 \%$ \\
Demographic intersectionality & & & \\
$\quad$ White male plaintiff $(\mathrm{N}=36)$ & $61 \%$ & $3 \%$ & $36 \%$ \\
White female plaintiff $(\mathrm{N}=20)$ & $55 \%$ & $10 \%$ & $35 \%$ \\
Nonwhite male plaintiff $(\mathrm{N}=196)$ & $69 \%$ & $14 \%$ & $17 \%$ \\
Nonwhite female plaintiff $(\mathrm{N}=109)$ & $71 \%$ & $17 \%$ & $13 \%$ \\
Plaintiffs race or sex is missing $(\mathrm{N}=653)$ & $53 \%$ & $15 \%$ & $32 \%$ \\
\hline
\end{tabular}

${ }^{24}$ The demographic intersectionality section of Table 4 compares outcomes for plaintiffs whose race and sex we were able to code from the judicial opinion. 
Table 5. Generalized Ordered Logistic Regressions of Employee Victory on Demographic and Claim Intersectionality

\begin{tabular}{|c|c|c|c|c|c|c|c|c|}
\hline \multirow[b]{3}{*}{$\begin{array}{l}\text { Independent } \\
\text { variables } \\
\end{array}$} & \multicolumn{2}{|c|}{ Model 1} & \multicolumn{2}{|c|}{ Model 2} & \multicolumn{2}{|c|}{ Model 3} & \multicolumn{2}{|c|}{ Model 4} \\
\hline & \multicolumn{2}{|c|}{$\begin{array}{c}\text { Claim } \\
\text { Intersectionality }\end{array}$} & \multicolumn{2}{|c|}{$\begin{array}{c}\text { Traditional } \\
\text { Demographics }\end{array}$} & \multicolumn{2}{|c|}{$\begin{array}{c}\text { Demographic } \\
\text { Intersectionality }\end{array}$} & \multicolumn{2}{|c|}{$\begin{array}{c}\text { Claim and } \\
\text { Demographic } \\
\text { Intersectionality }\end{array}$} \\
\hline & $\begin{array}{c}\text { At least } \\
\text { partial victory }\end{array}$ & $\begin{array}{c}\text { Complete } \\
\text { victory }\end{array}$ & $\begin{array}{c}\text { At least } \\
\text { partial victory }\end{array}$ & $\begin{array}{c}\text { Complete } \\
\text { victory }\end{array}$ & $\begin{array}{c}\text { At least } \\
\text { partial victory }\end{array}$ & $\begin{array}{c}\text { Complete } \\
\text { victory }\end{array}$ & $\begin{array}{c}\text { At least } \\
\text { partial victory }\end{array}$ & $\begin{array}{c}\text { Complete } \\
\text { victory }\end{array}$ \\
\hline \multicolumn{9}{|l|}{ Claims } \\
\hline Intersectional claim & $-0.63^{* *}(0.20)$ & $-1.00^{* * *}(0.24)$ & & & & & $-0.51 *(0.21)$ & $-0.90 * * *(0.25)$ \\
\hline $\begin{array}{l}\text { Multiple } \\
\text { nonintersectional } \\
\text { claims }\end{array}$ & $0.0062(0.17)$ & $-0.33^{t}(0.19)$ & & & & & $0.070(0.17)$ & $-0.22(0.19)$ \\
\hline \multicolumn{9}{|l|}{$\begin{array}{l}\text { Single claim } \\
\text { (omitted) }\end{array}$} \\
\hline \multicolumn{9}{|l|}{ Demographics } \\
\hline Nonwhite plaintiff & & & $-0.37(0.30)$ & $-1.17^{* * *}(0.31)$ & $-0.14(0.31)$ & $-0.94 * *(0.33)$ & $-0.17(0.32)$ & $-0.91^{* *}(0.33)$ \\
\hline \multicolumn{8}{|l|}{ White (omitted) } & $-0.67 *(0.30)$ \\
\hline Female plaintiff & & & $0.28^{\prime}(0.14)$ & $0.13(0.16)$ & $0.48 * *(0.17)$ & $0.33^{t}(0.18)$ & $0.47 * *(0.17)$ & $0.38 *(0.18)$ \\
\hline Missing sex & & & $1.25^{* * *}(0.25)$ & $1.11 * * *(0.24)$ & $1.24 * * *(0.24)$ & $1.10^{* * *}(0.24)$ & $1.26^{* * *}(0.25)$ & $1.12 * * *(0.24)$ \\
\hline $\begin{array}{l}\text { Male (omitted) } \\
\text { Nonwhite female }\end{array}$ & & & & & & & & \\
\hline $\begin{array}{l}\text { Nonwhite lemale } \\
\text { plaintiff }\end{array}$ & & & & & $-0.68^{*}(0.30)$ & $-0.73^{*}(0.36)$ & $-0.55^{1}(0.31)$ & $-0.64^{\circ}(0.37)$ \\
\hline
\end{tabular}

Standard errors in parentheses.

All models control for the number of challenged actions, circuit vs. district court, legal publication, length in pages, and post- 1986 .

**** $p<0.001,{ }^{* *} p<0.01,{ }^{*} p<0.05, p<0.1$. 
multiple aspects of the case, compared to plaintiffs who allege a single basis of discrimination, plaintiffs making intersectional claims have only about half the odds of attaining at least a partial victory and approximately one-third the odds of a complete victory.$^{25}$ All else equal, we predict that plaintiffs alleging only one basis of discrimination will win their cases 28 percent of the time, whereas plaintiffs bringing otherwise identical cases that allege intersectional bases of discrimination will win only 13 percent of the time. ${ }^{26}$ This finding provides strong evidence for the hypothesis that EEO law disadvantages plaintiffs who allege intersectional discrimination.

One interpretation of this finding might be that cases alleging multiple types of discrimination were intrinsically weaker, with desperate plaintiffs adding bases of discrimination and hoping that one would be successful. At least one federal judge adopts this view, suggesting that plaintiffs who allege multiple bases of discrimination are "throwing spaghetti at the wall to see what sticks" (district court judge Ruben Castillo, quoted in Kotkin 2009: 1442). We test for this possibility in three ways. First, we control for multiple challenged actions because desperate plaintiffs might be just as likely to challenge multiple employer actions (e.g., compensation and promotion) as to allege multiple bases of discrimination. We do find a significant negative effect of the number of challenged actions on complete plaintiff victory, but the effect's magnitude is much smaller than is the claim intersectionality effect. Second, if desperate plaintiffs were likely to add both challenged actions and bases of discrimination to their cases, then controlling for the number of challenged actions would decrease the size of the coefficient for intersectional claims. In fact, including the number of challenged actions in the model has no such effect. Third, if alleging multiple bases of discrimination were an indicator of intrinsically weak cases, it should not matter whether or not the additional alleged bases of discrimination are based on ascriptive characteristics. Our results show that whether the bases of discrimination are ascriptive or not matters: we find a large significant negative effect for intersectional claims (those alleging discrimination based on multiple ascriptive characteristics), but only a small, marginally significant effect for cases alleging multiple nonintersectional bases of discrimination (that is, cases in which only one or none of the alleged bases of discrimination is an ascriptive characteristic). These

\footnotetext{
${ }^{25}$ Odds ratios are obtained by exponentiating the coefficients.

${ }^{26}$ We calculated these predicted probabilities with all control variables held constant at their means or modes (two challenged employer actions, district court, published opinion, seven pages long, and post-1986).
} 
findings suggest that intersectional claims are not the result of plaintiffs' frivolously adding additional claims. ${ }^{27}$

Model 2 in Table 5 shows the effects of plaintiffs' demographics on the likelihood of employee victory without considering demographic intersectionality. Besides the control variables, Model 2 includes only the main effects for race and sex, which are measured by dummy variables for nonwhite plaintiffs and plaintiffs with missing race data (white plaintiffs are the omitted category) and variables for female plaintiffs and plaintiffs with missing sex data (male plaintiffs are the omitted category). Model 2 shows that all else equal, nonwhite plaintiffs have less than one-third of white plaintiffs' odds of achieving complete victories. Female plaintiffs are slightly more likely than male plaintiffs to achieve at least partial victories, but this coefficient is significant only at the .1 level. ${ }^{28}$ If we stopped at Model 2 (hence ignoring demographic intersectionality), as do previous studies, we would likely conclude that there are no important differences between men's and women's outcomes in EEO litigation.

Model 3 improves on Model 2 (and on previous research) because it accounts for demographic intersectionality by including a variable set to one if the plaintiff is a nonwhite woman. The interaction effect has a negative and statistically significant effect on plaintiffs' odds of at least partial victory and on plaintiffs' odds of complete victory. When we include it in the model, the main effect for sex becomes a significant predictor of at least partial plaintiff victory.

Based on Model 3, and holding all control variables constant at their means or modes, white women have the highest predicted probability of a full victory ( 38 percent), followed by white men (31 percent), nonwhite men (15 percent), and nonwhite women (11 percent). ${ }^{29}$ This intersectional relationship between race and sex can be understood in two ways. First, there are larger race effects for women than for men: nonwhite women fall further behind white women than nonwhite men fall behind white men. Second,

${ }^{27}$ While these results suggest that intersectional claims are not inherently weaker than other claims, the merit of cases cannot be conclusively discerned from written judicial opinions. A fuller measure of merit would require examination of the briefs, depositions, testimony, and other materials submitted in the context of litigation, independently measuring the underlying merit of cases and the law's construction of merit. Such an inquiry is beyond the scope of this analysis.

${ }^{28}$ Plaintiffs with missing sex were also significantly more likely to win their cases than were male plaintiffs. Most of this pattern is explained by the fact that many of these cases are class actions, which have high rates of plaintiff victory and also often have a mixed-sex group of plaintiffs.

${ }^{29}$ Kluegel and Smith (1986) show that Americans tend to be skeptical of the existence of racial discrimination while giving more credence to the idea that white women face sex discrimination. This pattern may help explain white women's high win rates. 
there are different gender effects for whites and nonwhites: white women get ahead of white men, while nonwhite women fare similarly to nonwhite men. ${ }^{30}$ Our findings, then, suggest that studies that fail to account for demographic intersectionality miss the fact that sex and race disadvantages do not operate independently in the courts.

Whereas Models 1 and 3 in Table 5 consider demographic and claim intersectionality separately, Model 4 includes both, thus allowing us to test whether either intersectionality effect is an artifact of omitted variable bias. Given that plaintiffs making intersectional claims are disproportionately likely to be nonwhite women (see Table 3), the effect of claim intersectionality observed in Model 1 might actually reflect nonwhite women's disadvantage. Alternatively, the negative coefficient for nonwhite women in Model 3 might be explained by the fact that nonwhite women are disproportionately likely to make intersectional claims (see Table 3). Model 5 shows, however, that each type of intersectionality has an independent effect on plaintiffs' likelihood of winning. The claim intersectionality coefficient remains statistically significant and decreases only slightly. Regarding demographic intersectionality, the interaction effect between plaintiffs' race and sex is only significant at the $p<0.1$ level in Model 4 , but its magnitude is virtually unchanged. The fact that the coefficients for both measures of intersectionality remain large and at least marginally statistically significant when included in the same model suggests that demographic and claim intersectionality represent two distinct pathways of disadvantage for plaintiffs. Demographic and claim intersectionality are each associated with dramatically reduced odds of plaintiff victory.

Figures 2 and 3 show the magnitude of the effects of each type of intersectionality, net of the other, with all other variables held constant at their means or modes. Figure 2 shows the effects of claim intersectionality net of demographic intersectionality by giving the predicted probabilities of complete victories for nonwhite female plaintiffs who do and do not assert intersectional claims. Even among nonwhite female plaintiffs, intersectional claims are predicted to prevail only half as often as single claims. Figure 3 shows the effects of demographic intersectionality net of claim intersectionality by giving the predicted probabilities of complete victories in single-claim cases for plaintiffs at each intersection of race and sex. Even when controlling for their increased likelihood of making intersectional claims, nonwhite female plaintiffs still have the lowest predicted probability of winning their cases.

${ }^{30}$ The differences in outcomes between nonwhite men and nonwhite women are not statistically significant. 


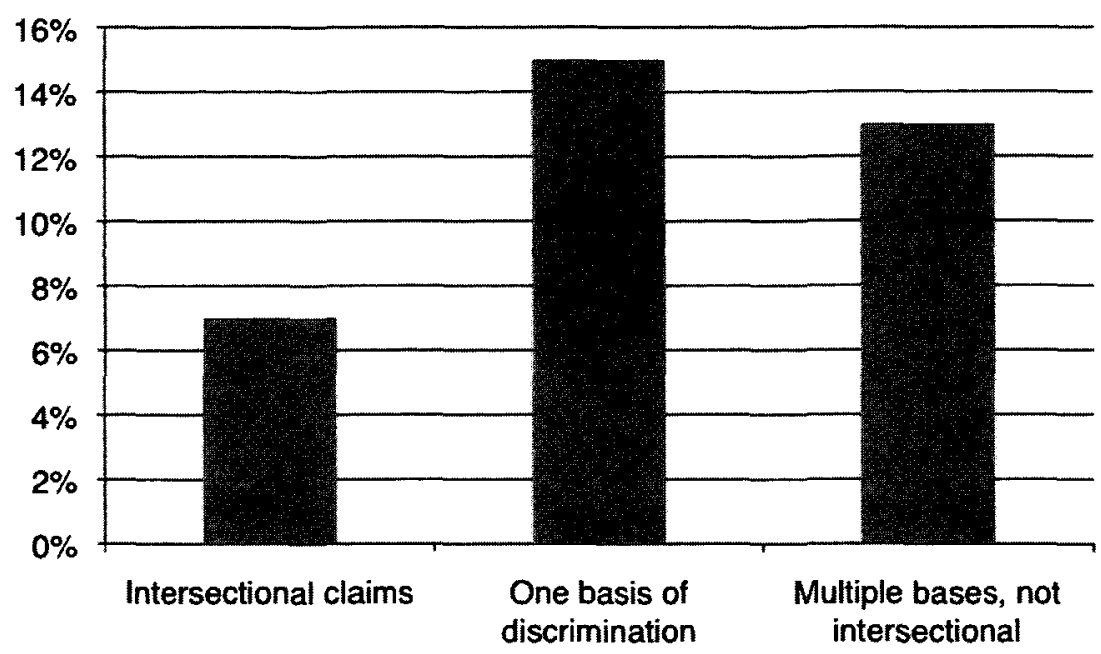

Figure 2. Effects of claim intersectionality, net of demographic intersectionality: predicted probabilities of complete employee victory for nonwhite women, holding controls constant at their means or modes.

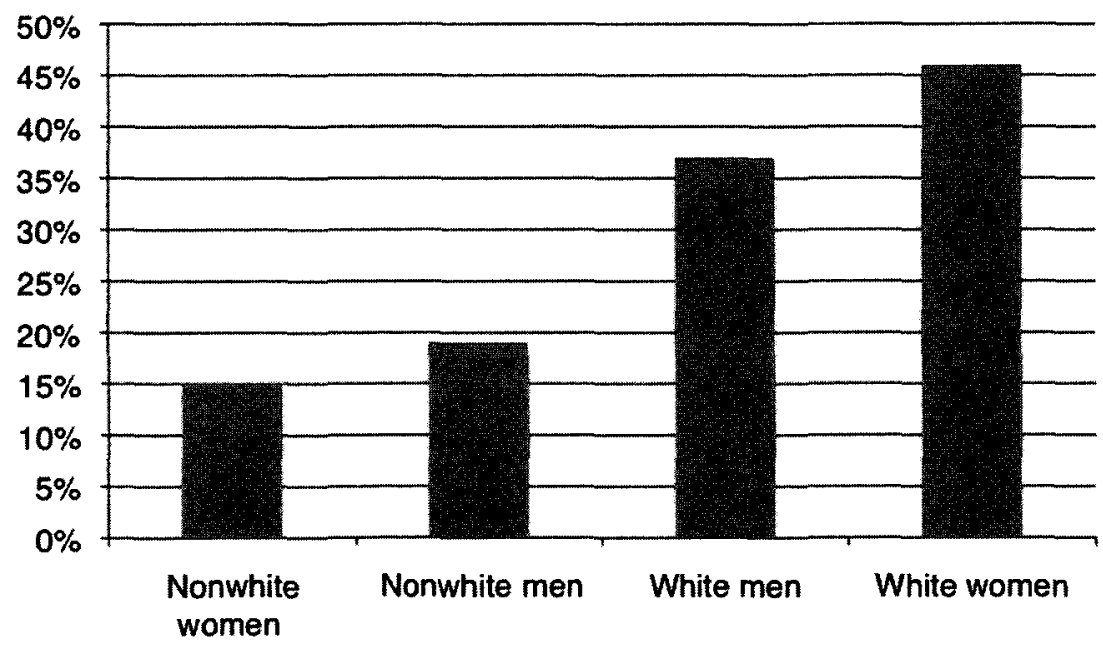

Figure 3. Effects of demographic intersectionality, net of claim intersectionality: predicted probabilities of complete employee victory for single-claim cases, holding controls constant at their means or modes.

Mediating Variables: Mechanisms for the Intersectionality Penalty

To explore how intersectionality disadvantages plaintiffs, we consider several variables that might mediate the effects of demographic and claim intersectionality on plaintiff victory. In Table 6, 
Table 6. Mechanisms for Intersectionality Effects

\begin{tabular}{|c|c|c|c|c|c|c|c|c|}
\hline \multirow[b]{3}{*}{$\begin{array}{l}\text { Independent } \\
\text { variables }\end{array}$} & \multicolumn{2}{|c|}{ Model 4} & \multicolumn{2}{|c|}{ Model 5} & \multicolumn{2}{|c|}{ Model 6} & \multicolumn{2}{|c|}{ Model 7} \\
\hline & \multicolumn{2}{|c|}{ Base Model } & \multicolumn{2}{|c|}{$\begin{array}{c}\text { Add Section } \\
\text { 1981/Title VII }\end{array}$} & \multicolumn{2}{|c|}{ Add Deference } & \multicolumn{2}{|c|}{$\begin{array}{c}\text { Add Resources, } \\
\text { Doctrine, Evidence }\end{array}$} \\
\hline & $\begin{array}{l}\text { At least partial } \\
\text { victory }\end{array}$ & $\begin{array}{l}\text { Complete } \\
\text { victory }\end{array}$ & $\begin{array}{c}\text { At least partial } \\
\text { victory }\end{array}$ & $\begin{array}{c}\text { Complete } \\
\text { victory }\end{array}$ & $\begin{array}{l}\text { At least partial } \\
\text { victory }\end{array}$ & $\begin{array}{c}\text { Complete } \\
\text { victory }\end{array}$ & $\begin{array}{c}\text { At least partial } \\
\text { victory }\end{array}$ & $\begin{array}{c}\text { Complete } \\
\text { victory }\end{array}$ \\
\hline \multicolumn{9}{|l|}{$\begin{array}{l}\text { Claims (single claim } \\
\text { omitted) }\end{array}$} \\
\hline $\begin{array}{l}\text { Intersectional claim } \\
\text { Claim intersec. } x \\
\text { Title VII \& Section } \\
1981\end{array}$ & $-0.51 *(0.21)$ & $-0.90^{* * *}(0.25)$ & $\begin{array}{r}-0.49^{*}(0.24) \\
-0.21(0.41)\end{array}$ & $\begin{array}{r}-0.60^{*}(0.28) \\
-1.07^{*}(0.56)\end{array}$ & $\begin{array}{l}-0.21(0.25) \\
-0.33(0.44)\end{array}$ & $\begin{array}{r}-0.34(0.29) \\
-1.21 *(0.58)\end{array}$ & $\begin{array}{r}-0.096(0.26) \\
-0.36(0.45)\end{array}$ & $\begin{array}{r}-0.20(0.30) \\
-1.50^{*}(0.60)\end{array}$ \\
\hline $\begin{array}{l}\text { Multiple } \\
\text { nonintersectional } \\
\text { claims }\end{array}$ & $0.070(0.17)$ & $-0.22(0.19)$ & $0.048(0.17)$ & $-0.22(0.19)$ & $0.079(0.18)$ & $-0.20(0.20)$ & $0.13(0.19)$ & $-0.22(0.20)$ \\
\hline \multicolumn{9}{|l|}{$\begin{array}{l}\text { Demographics (white } \\
\text { males omitted) }\end{array}$} \\
\hline Nonwhite plaintiff & $-0.17(0.32)$ & $-0.91^{* *}(0.33)$ & $-0.20(0.32)$ & $-0.95^{* *}(0.33)$ & $0.0050(0.33)$ & $-0.80 *(0.34)$ & $-0.039(0.34)$ & $-0.95^{* *}(0.36)$ \\
\hline Missing race & $-0.090(0.29)$ & $-0.67 *(0.30)$ & $-0.014(0.29)$ & $-0.65 *(0.30)$ & $0.082(0.31)$ & $-0.58^{t}(0.32)$ & $0.082(0.32)$ & $-0.64^{*}(0.33)$ \\
\hline Female plaintiff & $0.47 * *(0.17)$ & $0.38 *(0.18)$ & $0.45^{* *}(0.17)$ & $0.38 *(0.18)$ & $0.44^{*}(0.18)$ & $0.35^{\mathrm{x}}(0.19)$ & $0.31^{\circ}(0.19)$ & $0.26(0.20)$ \\
\hline Missing sex & $1.26^{* * *(0.25)}$ & $1.12 * * *(0.24)$ & $1.24 * * *(0.25)$ & $1.13^{* * *}(0.24)$ & $1.05^{* * *}(0.26)$ & $0.97^{* * *}(0.25)$ & $1.09 * * *(0.28)$ & $0.68 *(0.28)$ \\
\hline $\begin{array}{l}\text { Nonwhite female } \\
\text { plaintiff }\end{array}$ & $-0.55^{\prime}(0.31)$ & $-0.64^{\prime}(0.37)$ & $-0.55^{\mathrm{t}}(0.31)$ & $-0.59(0.36)$ & $-0.64 *(0.32)$ & $-0.59(0.38)$ & $-0.60^{\prime}(0.33)$ & $-0.52(0.39)$ \\
\hline \multicolumn{9}{|l|}{ Mediators } \\
\hline $\begin{array}{l}\text { Title VII \& Section } \\
1981\end{array}$ & & & $0.45^{*}(0.21)$ & $0.28(0.23)$ & $0.42^{\mathrm{t}}(0.22)$ & $0.19(0.24)$ & $0.38^{\mathrm{x}}(0.23)$ & $0.29(0.24)$ \\
\hline Judicial deference & & & & & $-1.71 * * *(0.19)$ & $-1.84 * * *(0.24)$ & $-1.72 * * *(0.19)$ & $-1.88 * * *(0.25)$ \\
\hline $\begin{array}{l}\text { Resources and } \\
\text { procedural } \\
\text { posture }^{1}\end{array}$ & & & & & & & $\mathrm{X}$ & $\mathrm{X}$ \\
\hline
\end{tabular}

All models control for the number of challenged actions, circuit vs. district court, legal publication, length in pages, and post-1986.

${ }^{1}$ Government or public-interest involvement, occupational prestige, unionization, summary judgment, and motion to dismiss.

Standard errors in parentheses. ${ }^{* * * *} p<0.001,{ }^{* *} p<0.01,{ }^{*} p<0.05,{ }^{t} p<0.1$. 
we sequentially add mediating variables to Model 4 to see whether they decrease the size and significance of the claim intersectionality coefficient or the race/sex interaction effect. Model 4 is repeated in Table 6 for comparison of the coefficients. Mediating variables that decrease the effects of the intersectionality variables tell us something about how the intersectionality penalty works.

First, to test Smith's (1991) hypothesis that intersectional claims fare especially poorly when plaintiffs bring claims under both Section 1981 and Title VII, Model 5 adds a dummy variable set to one when the plaintiff brings claims under both statutes and an interaction effect between this variable and intersectional claims. Consistent with Smith's argument, there is a large negative interaction effect between intersectional claims and the Title VII/Section 1981 combination on the odds of employee victory. The coefficient is large, but is only significant at the .1 level; it becomes larger and statistically significant with the inclusion of more control variables in Models 6 and 7. The Title VII/Section 1981 combination is actually advantageous when not combined with intersectional claims; plaintiffs alleging only one type of discrimination under both Title VII and Section 1981 have a higher predicted probability of a full victory ( 37 percent) than plaintiffs who do not combine the two statutes ( 30 percent). Intersectional claims have lower rates of plaintiff victory even without this particular combination of statutes (19 percent), and plaintiffs who make intersectional claims under both Title VII and Section 1981 have the lowest win rate of all (10 percent). ${ }^{31}$ Thus, Smith is correct that plaintiffs who make intersectional claims under the two statutes are especially unlikely to win their cases.

Next, we explore whether judicial deference to organizational structures mediates the effects of intersectionality. As mentioned earlier, legal endogeneity theory (Edelman et al. 1999; Edelman et al. 2011) suggests that judges may be especially likely to view institutionalized structures such as grievance procedures or formal notice policies as evidence of nondiscriminatory treatment when they are skeptical of the plaintiffs or their claims, making judicial deference a potential mechanism for the intersectionality penalty. Model 6 in Table 6 explores this possibility by including a dichotomous variable indicating whether any structures were deferred to. ${ }^{32}$

${ }^{31}$ Predicted probabilities were calculated with all control variables set at their means or modes.

${ }^{32}$ The judicial deference variable is set to one where judges viewed the presence of an organizational structure as potential evidence of nondiscrimination and the opinion reflects no consideration of the quality or adequacy of the structure, explicitly states that the structure is inadequate but that the inadequacy does not matter, or gives superficial consideration to the question of adequacy but the opinion includes clear indicators that the structure was inadequate. 
When we include judicial deference in the model, the coefficients for plaintiffs' demographics remain virtually unchanged; thus, judicial deference does not mediate the effects of demographic intersectionality. Likewise, the interaction effect between claim intersectionality and the Title VII/Section 1981 combination remains large and statistically significant. However, the main effect for claim intersectionality is reduced by half and loses statistical significance. Thus, in cases with intersectional claims that do not involve both Title VII and Section 1981, judges are more likely to defer to employers' structures, and this increased likelihood of deference is an important mediator of the disadvantage faced by plaintiffs bringing intersectional claims.

In Model 7, we add three indicators of the resources available to plaintiffs (unionization, involvement of government or publicinterest organizations, and plaintiffs' occupational prestige) and two variables related to the procedural posture that may indicate the presence of doctrinal barriers or evidentiary hurdles (motion to dismiss and summary judgment). When these variables are included, the coefficients for the claim intersectionality main effect decrease further; however, they were already small and nonsignificant before the addition of these controls. Including the new variables has little effect on any of the coefficients for plaintiffs' demographics and actually increases the coefficient for the claim intersectionality/Title VII/Section 1981 interaction effect. Thus, our rough measures of resources, doctrinal barriers, and evidentiary hurdles explain little to none of the claim and demographic intersectionality penalties. ${ }^{33}$

\section{Discussion}

Our analysis provides the first systematic empirical test of intersectionality theory by examining the effects of both demographic intersectionality and claim intersectionality on plaintiff win rates in employment discrimination cases. We find strong support for the ideas that race and sex disadvantages do not operate independently in the courts (demographic intersectionality) and that antidiscrimination law provides less protection in cases that involve intersecting bases of discrimination (claim intersectionality).

3s In other models, we also controlled for judges' political orientations, measured using the judicial common space score method proposed by Giles et al. (2001). Michael Giles generously provided us with scores for circuit court judges, and we used data from the National Judicial Center to calculate scores for district court judges. Judges' political orientations were not statistically significant and did not affect the intersectionality coefficients. 
Our results suggest, moreover, that these two types of intersectionality represent two distinct processes of disadvantage. Although nonwhite women are more likely to bring intersectional claims, this does not explain all of the disadvantage they face in court. Likewise, claim intersectionality harms plaintiffs' chances of winning, regardless of their demographic characteristics. EEO law itself seems to disadvantage intersectional plaintiffs, above and beyond any discrimination they may face in the courtroom on the basis of their race or sex.

Previous research suggested three main reasons why intersectional claims might disadvantage plaintiffs: (1) the categorical nature of discrimination law creates doctrinal barriers to intersectional claims, (2) there are evidentiary hurdles to demonstrating intersectional discrimination, and (3) judicial skepticism about intersectional claims may make intersectional plaintiffs less likely to win their cases. Our findings suggest that the Title VII/Section 1981 combination does pose a doctrinal barrier that mediates the effects of claim intersectionality and thus supports Smith's (1991) argument that judges tend to believe that intersectional claims can be neatly separated and that a ruling against the plaintiffs' race allegations under Section 1981 prohibits consideration of race intersections under Title VII. Our findings also suggest that judicial deference may be an important mechanism through which claim intersectionality penalizes plaintiffs. Controlling for judicial deference explains most of the claim intersectionality penalty for cases that are not brought under both Title VII and Section 1981. The fact that judicial deference is especially likely in cases involving intersectional claims elaborates Edelman et al.'s (1999, 2011) suggestion that judges treat institutionalized organizational structures as symbolic indicia of employers' rationality and compliance. In sum, although our data do not permit a direct test of the mechanisms through which intersectionality operates, we find some support for the ideas that intersectional claims are held back by a combination of doctrinal barriers and judicial interpretations.

Our findings have important implications for several theoretical debates in the intersectionality literature. One point of disagreement among scholars is whether intersectionality applies only to members of traditionally disadvantaged groups or whether all identities are intersectional (Browne \& Misra 2003; Davis 2008; Nash 2008). Some researchers subscribe to a "multiple jeopardy" approach that assumes that women of color are more disadvantaged than other groups in all contexts (King 1988; Ransford 1980). However, recent critiques of the intersectionality literature from within argue that when limited to the case of black women, intersectionality is insufficiently developed as a general theory 
(Nash 2008), and view intersectionality as a broader theory that can apply "to any grouping of people, advantaged as well as disadvantaged" (Yuval-Davis 2006, 201; see also Chang \& Culp 2002; Kwan 1996; Zack 2005). A related debate focuses on whether intersectional disadvantages are "ubiquitous or contingent" (Browne \& Misra 2003: 492). Some scholars argue that intersectionality affects outcomes and experiences in every social setting (Collins 1990; Weber 2001), while others suggest that its effects are contingent, with single categories sometimes dominating (McCall 2005; Yuval-Davis 2006). Our findings demonstrate that intersectionality is context dependent. Whereas intersectionality theory generally presumes that white men tend to fare the best and nonwhite women are the most disadvantaged, our findings suggest a somewhat different pattern. In our sample, white female plaintiffs had the highest chances of winning their cases, a pattern that is likely specific to the context of EEO litigation.

Our analysis also has methodological implications for the intersectionality literature. Most of the intersectionality literature to date has employed rich qualitative analyses, which have revealed much about the nature of intersectional disadvantage and intersectionality's effects on particular plaintiffs and in particular cases. But until now, we have known little about the general effects of intersectionality on litigation outcomes. Our work demonstrates the power of quantitative methods and categorization for documenting inequalities in litigation and judicial decisionmaking.

In addition to contributing to the intersectionality literature in critical race theory, our work has important implications for emerging research in social psychology and stratification, which demonstrates that intersectional discrimination occurs in the labor market. Our findings regarding demographic intersectionality demonstrate that intersecting demographic characteristics shape outcomes in the courts as well as in the labor market. Moreover, our findings regarding claim intersectionality establish that EEO law provides little protection for plaintiffs facing intersectional discrimination in the labor market.

Plaintiffs who suffer multiple disadvantages in society fare worse than do singly disadvantaged plaintiffs when they seek to assert their civil rights in court. This disadvantage operates both through demographic intersectionality, where the intersection of race and sex puts black women at a disadvantage, and through claim intersectionality, where those who assert two or more types of discrimination fare worse than do those whose cases are simpler. By assuming that disadvantages based on race, sex, and other ascriptive characteristics operate independently, civil rights law perpetuates intersectional disadvantages. 


\section{References}

Abrams, Kathryn (1994) "Title VII and the Complex Female Subject," 92 Michigan Law Rev. 2479-2540.

Albiston, Catherine (1999) "The Rule of Law and the Litigation Process: The Paradox of Losing by Winning," 33 Law E Society Rev. 869-910.

Albiston, Catherine R. (2005) "Bargaining in the Shadow of Social Institutions: Competing Discourses and Social Change in Workplace Mobilization of Civil Rights," 39 Law E Society Rev. 11-49.

Austin, Regina (1989) "Sapphire Bound!" 1989 Wisconsin Law Rev. 539-578.

Babcock, Barbara Allen (1993) "Report of the Ninth Circuit Gender Bias Task Force: Introduction: Gender Bias in the Courts and Civic and Legal Education," 45 Stanford Law Rev. 2143-2152.

Baldus, David C., George Woodworth, \& Charles A. Pulaski (1990) Equal Justice and the Death Penalty: $A$ Legal and Empirical Analysis. Boston: Northeastern Univ. Press.

Beller, Andrea (1982) "The Impact of Equal Opportunity Policy on Sex Differentials in Earnings and Occupations," 72 American Economic Rev. 171-175.

Bisom-Rapp, Susan (1999) "Bulletproofing the Workplace: Symbol and Substance in Employment Discrimination Law Practice," 26 Florida State Univ. Law Review 9591038.

(2001) "Fixing Watches with Sledgehammers: The Questionable Embrace of Employee Sexual Harassment Training by the Legal Profession," 24 University of Arkansas Little Rock Law Rev. 147-168.

Bodenhausen, Galen V. (2010) "Diversity in the Person, Diversity in the Group: Challenges of Identity Complexity for Social Perception and Social Interaction," 40(1) European J. of Social Psychology 1-16.

Brant, Rollin (1990) "Assessing Proportionality in the Proportional Odds Model for Ordinal Logistic Regression," 46 Biometrics 1171-1178.

Browne, Irene, \& Joya Misra (2003) "The Intersection of Gender and Race in the Labor Market," 29 Annual Rev. of Sociology 487-513.

Bumiller, Kristin (1987) "Victims in the Shadow of the Law: A Critique of the Model of Legal Protection," 12 Signs 421-434.

- (1988) The Civil Rights Society: The Social Construction of Victims. Baltimore: Johns Hopkins University Press.

Burstein, Paul, \& Mark Evan Edwards (1994) "The Impact of Employment Discrimination Litigation on Racial Disparity in Earnings: Evidence and Unresolved Issues," 28 Law E Society Rev. 79-112.

\& Kathleen Monaghan (1986) "Equal Employment Opportunity and the Mobilization of Law," Law \& Society Rev. 20 355-388.

Caldwell, Paulette (1991) "A Hair Piece: Perspectives on the Intersection of Race and Gender," 1991 Duke Law J. 365-396.

Carbado, Devon W., \& Mitu Gulati (2001) "The Fifth Black Woman," $11 \mathrm{~J}$. of Contemporary Legal Issues 701-729.

Chang, Robert S., \& Jerome McCristal Culp, Jr (2002) "After Intersectionality," 71 University of Missouri Kansas City Law Rev. 485-491.

Collins, Patricia Hill (1990) Black Feminist Thought: Knowledge, Consciousness and the Politics of Empowerment. New York: Routledge.

Crenshaw, Kimberlé Williams (1989) "Demarginalizing the Intersection of Race and Sex: A Black Feminist Critique of Antidiscrimination Doctrine, Feminist Theory and Antiracist Policies," The Univ. of Chicago Legal Forum 139-167.

(1991) "Mapping the Margins: Intersectionality, Identity Politics, and Violence Against Women of Color," 43 Stanford Law Rev. 1241-1299.

(1992) "Race, Gender, and Sexual Harassment," 65 Southern Califormia Law Rev. $1467-1476$. 
Cunningham, E. Christi (1998) "The Rise of Identity Politics I: The Myth of the Protected Class in Title VII Disparate Treatment Cases," 30 Connecticut Law Rev. 441-501.

Davis, Kathy (2008) "Intersectionality as Buzzword: A Sociology of Science Perspective on What Makes a Feminist Theory Successful," 9 Feminist Theory 67-85.

Delgado, Richard, ed. (1995) Critical Race Theory: The Cutting Edge. Philadelphia: Temple Univ. Press.

Eberts, Randall W., \& Joe A. Stone (1985) "Male-Female Differences in Promotions: EEO in Public Education," $20 \mathrm{~J}$. of Human Resources 504-521.

Edelman, Lauren B. (1992) "Legal Ambiguity and Symbolic Structures: Organizational Mediation of Civil Rights Law," 97 American J. of Sociology 1531-1576. (2005) "Law at Work: The Endogenous Construction of Civil Rights," in Nelson, Robert L., \& Laura Beth Nielsen, eds., Handbook on Employment Discrimination Research: Rights and Realities. Norwell, MA: Kluwer Academic Press. pp. 337352

- (2007) "Overlapping Fields and Constructed Legalities: The Endogeneity of Law," in O'Brien, Justin, ed., Private Equity, Corporate Governance, and the Dynamics of Capital Market Regulation. London: World Scientific. pp. 55-90

—_ et al. (1993) "Internal Dispute Resolution: The Transformation of Civil Rights in the Workplace," 27 Law E' Society Rev. 497-534.

—_, et al. (1999) "The Endogeneity of Legal Regulation: Grievance Procedures as Rational Myth," 105 American Journal of Sociology 406-454.

—_, et al. (2011) "When Organizations Rule: Judicial Deference to Institutionalized Organizational Structures," 117 American J. of Sociology (in press).

Felstiner, William L.F., et al. (1980/1981) "The Emergence and Transformation of Disputes: Naming Blaming, Claiming," 15 Law E Society Rev. 631-654.

Galanter, Marc (1974) "Why the 'Haves' Come Out Ahead: Speculations on the Limits of Legal Change," 9 Law \& Society Rev. 95-160.

Gerken, Joseph L. (2004) “A Librarian's Guide to Unpublished Judicial Opinions,” 96 Law Library J. 475-502.

Giles, Michael W., et al. (2001) "Picking Federal Judges: A Note on Policy and Partisan Selection Agendas," 64 Political Research Q. 623-641.

Gomez, Laura E. (2004) "A Tale of Two Genres: On the Real and Ideal Links Between Law and Society and Critical Race Theory," in Sarat, Austin, ed., Blackwell Companion to Law and Society. New York: 454-470. Blackwell.

Guthrie, Chris, Jeffrey J. Rachlinski, \& Andrew J. Wistrich. (2007) "Blinking on the Bench: How Judges Decide Cases," 93 Cornell Law Rev. 1-44.

Haney Lopez, Ian F. (2000) "Institutional Racism: Judicial Conduct and a New Theory of Racial Discrimination," 109 Yale Law Rev. 1717.

Harris, Angela (1990) "Race and Essentialism in Feminist Legal Theory," 42 Stanford Law Rev. 581.

Harris, Cheryl (1997) "Finding Sojourner's Truth: Race, Gender and the Institution of Property,” 18 Cardozo Law Rev. 309.

Harvey, Adia M. (2005) "Becoming Entrepreneurs: Intersections of Race, Class, and Gender at the Black Beauty Salon," 19 Gender and Society 789-808.

Heckman, James J., \& J. Hoult Verkerke (1990) "Racial Disparity and Employment Discrimination Law: An Economic Perspective," 8 Yale Law and Policy Rev. 276299.

Hondagneu-Sotelo, Pierrette (2001) Domestica: Immigrant Workers Cleaning and Caring in the Shadows of Affluence. Berkeley, CA: Univ. of California Press.

Hutter, Russell R. C., \& Richard J. Crisp (2005) "The Composition of Category Conjunctions," 31 Personality and Social Psychology Bulletin 647-657.

Kalev, Alexandra, et al. (2006) "Best Practices or Best Guesses? Assessing the Efficacy of Corporate Affirmative Action and Diversity Policies," 71 American Sociological Rev. 589-617. 
Kaufman, Robert L. (2002) "Assessing Alternative Perspectives on Race and Sex Employment Segregation," 67 American Sociological Rev. 547-572.

Kennelly, Ivy (1999) "That Single Mother Element: How White Employers Typify Black Women," 13 Gender and Society 168-192.

King, Deborah K. (1988) "Multiple Jeopardy, Multiple Consciousness: The Context of a Black Feminist Ideology," 14 Signs 42-72.

Kirschenman, Joleen, \& Kathryn M. Neckerman (1991) "We'd Love to Hire Them But. ..: The Meaning of Race to Employers," in Jencks, Christopher, \& Paul Peterson, eds., The Urban Underclass. Washington, DC: Brookings Institution.

Kluegel, James R., \& Eliot R. Smith (1986) Beliefs about Inequality: Americans' Views of What Is and What Ought to Be. New York: Transaction Books.

Kotkin, Minna (2009) "Diversity and Discrimination: A Look at Complex Bias," 50 William and Mary Law Rev. 1439-1500.

Krieger, Linda (1995) "The Content of Our Categories: A Cognitive Bias Approach to Discrimination and Equal Employment Opportunity," 47 Stanford Law Rev. 11611248.

Kunda, Ziva, \& Paul Thagard (1996) "Forming Impressions from Stereotypes, Traits, and Behaviors: A Parallel-Constraint-Satisfaction Theory," 103 Psychological Rev. 284-308.

Kwan, Peter (1996) "Jeffrey Dahmer and the Cosynthesis of Categories," 48 Hastings Law J. 1257-1292.

Leonard, Jonathan S. (1984) "The Impact of Affirmative Action on Employment," 2 $J$. of Labor Economics 439.

(1986) "The Effectiveness of Equal Employment Law and Affirmative Action Regulation," 8 Research in Labor Economics 319.

Long, J. Scott (1997) Regression Models for Categorical and Limited Dependent Variables. Thousand Oaks, CA: SAGE Publications.

Marshall, Anna-Maria (2005) 'Idle Rights: Employees' Rights Consciousness and the Construction of Sexual Harassment Policies," 39 Law E Society Rev. 83-123.

McCall, Leslie (2001) "Sources of Racial Wage Inequality in Metropolitan Labor Markets: Racial, Ethnic, and Gender Differences," 66 American Sociological Rev. 520-541.

(2005) "The Complexity of Intersectionality," 30 Signs: J. of Women in Culture and Society $1771-1800$.

Miller, Richard E., \& Austin Sarat (1980) "Grievances, Claims, and Disputes: Assessing the Adversary Culture," 15 Law \& Society Rev. 525-565.

Moss, Philip 1., \& Chris Tilly (2001) Stories Employers Tell: Race, Skills, and Hiring in America. New York: Russell Sage Foundation.

Nakao, Keiko, \& Judith Treas (1992) "The 1989 Socioeconomic Index of Occupations: Construction from the 1989 Occupational Prestige Scores," 74 General Social Survey Methodological Reports 1-32.

Nash, Jennifer C. (2008) "re-thinking intersectionality," 89 Feminist Rev. 115.

Nelson, Dorothy W. (1994) "Introduction to the Effects of Gender in the Federal Courts: The Final Report of the Ninth Circuit Gender Bias Task Force," 67 Southern Califormia Law Rev. 731-738.

Nelson, Robert L., \& William Bridges (1999) Legalizing Gender Inequality: Courts, Markets and Unequal Pay for Women. Cambridge: Cambridge Univ. Press.

Nielsen, Laura Beth (2004a) "The Power of Place: Public Space and Rights Consciousness," in Fleury-Steiner, Ben, \& Laura Beth Nielsen, eds., New Civil Rights Research. A Constitutive Approach. Burlington, VT: Ashgate Press. pp. 217-232.

(2004b) "The Work of Rights and the Work That Rights Do," in Sarat, Austin, ed., Blackwell Companion to Law and Society. New York: Blackwell.

—_ et al. (2010) "Individual Justice or Collective Legal Mobilization? Employment Discrimination Litigation in the Post-Civil Rights United States," $7 \mathrm{~J}$. of Empirical Legal Studies 175-201. 
Oppenheimer, David B. (2003) "Verdicts Matter: An Empirical Study of California Employment Discrimination and Wrongful Discharge Jury Verdicts Reveals Low Success Rates for Women and Minorities," 37 Univ. of California, Davis Law Rev. $511-566$.

Ransford, H. Edward (1980) "The Prediction of Social Behavior and Attitudes: The Correlates Tradition," in Jeffries, Vincent, \& H. Edward Ransford, eds., Social Stratification: A Multiple Hierarchies Approach. Boston: Allyn and Bacon.

Resnik, Judith (1991) "Naturally' Without Gender: Women, Jurisdiction, and the Federal Courts," 66 New York Univ. Law Rev. 1682-1673.

Richards, Zoee, \& Miles Hewstone (2001) "Subtyping and Subgrouping: Processes for the Prevention and Promotion of Stereotype Change," 5 Personality and Social Psychology Rev. 52-73.

Ridgeway, Cecilia L. (1997) "Interaction and conservation of gender inequality: considering employment," 62 American Sociological Rev. 218-235.

Roberts, Dorothy (1991) "Punishing Drug Addicts Who Have Babies: Women of Color, Equality and the Right of Privacy," 104 Harvard Law Rev. 1419-1482.

Roccas, Sonia, \& Marilynn B. Brewer (2002) "Social Identity Complexity," 6 Personality and Social Psychology Rev. 88-106.

Scales-Trent, Judy (1989) "Black Women and the Constitution: Finding Our Place, Asserting Our Rights," 24 Harvard Cizil Rights-Civil Liberties Law Rev. 944.

Schafran, Lynn Hecht (1998) "Will Inquiry Produce Action? Studying the Effects of Gender in the Federal Courts," 32 Univ. of Richmond Law Rev. 615646.

Scheingold, Stuart (1974) The Politics of Rights. New Haven, CT: Yale Univ. Press.

Schultz, Vicki (1990) "Telling Stories about Women and Work: Judicial Interpretations of Sex Segregation in the Workplace in Title VII Cases Raising the Lack of Interest Argument," 103 Harvard Law Rev. 1750-1843.

- \& Stephen Petterson (1992) "Race, Gender, Work, and Choice: An Empirical Study of the Lack of Interest Defense in Title VII Cases Challenging Job Segregation," 59 Univ. of Chicago Law Rev. 1073-1181.

Selby, Myra C. (1999) "Examining Race and Gender Bias in the Courts: A Legacy of Indifference or Opportunity?" 32 Indiana Law Rev. 1167-1186.

Shih, Johanna (2002) ' 'Yeah, I could hire this one, but I know it's gonna be a problem': How Race, Nativity and Gender Affect Employers' Perceptions of the Manageability of Job Seekers," 25 Ethnic and Racial Studies 99-119.

Siegelman, Peter, \& John J. Donohue III (1990) "Studying the Iceberg From Its Tip: A Comparison of Published and Unpublished Employment Discrimination Cases," 24 Law E' Society Rev. 1133-1170.

Skaggs, Sheryl (2008) "Producing Change or Bagging Opportunity? The Effects of Discrimination Litigation on Women in Supermarket Management," 113 American J. of Sociology 1148-1182.

(2009) "Legal-Political Pressures and African American Access to Managerial Jobs," 74 American Sociological Rev. 225.

Smith, Peggie R. (1991) "Separate Identities: Black Women, Work, and Title VII," 14 Harvard Women's Law J. 21-75.

Stangor, Charles, et al. (1992) "Categorization of Individuals on the Basis of Multiple Social Features," 62 J. of Personality and Social Psychology 207-218.

Sturm, Susan (2001) "Second Generation Employment Discrimination: A Structural Approach," 101 Columbia Law Rev. 458-568.

_ \& Lani Guinier (1996) "The Future of Affirmative Action: Reclaiming the Innovative Ideal," 84 California Law Rev. 953-1036.

Turner, Margery Austin, et al. (1991) Opportunities Denied, Opportunities Diminished: Racial Discrimination in Hiring. Washington, DC: Urban Institute Press.

Wald, Patricia (1998) "Summary Judgment at 60," 76 Texas Law Rev. 1897. 
Weber, Lynn (2001) Understanding Race, Class, Gender, and Sexuality: A Conceptual Framework. Boston: McGraw-Hill.

Wei, Virginia W. (1996) "Asian Women and Employment Discrimination: Using Intersectionality Theory to Address Title VII Claims Based on Combined Factors of Race, Gender and National Origin," 37 Boston College Law Rev. 771812.

West, Candace, \& Sarah Fenstermaker (1995) "Doing Difference," 9 Gender and Society 8-37.

Williams, Patricia J. (1991) The Alchemy of Race and Rights. Cambridge, Mass: Harvard Univ. Press.

Wolfe, Rory, \& William Gould (1998) "An Approximate Likelihood-Ratio Test for Ordinal Response Models," 42 Stata Technical Bulletin 24-27.

Yuval-Davis, Nira (2006) "Intersectionality and Feminist Politics," 13 European J. of Women's Studies 193-209.

Zack, Naomi (2005) Inclusive Feminism: A Third Wave Theory of Women's Commonality. Lanham, MD: Rowman \& Littlefield Publishers, Inc.

\section{Cases Cited}

Anderson v. Liberty Lobby, Inc., 477 U.S. 242 (1984).

Celotex Corp. v. Catrett, 477 U.S. 317 (1986).

DeGraffenreid v. General Motors, 413 F. Supp. 142 (E.D. Mo. 1976).

Jefferies v. Harris County Community Action Association (615 F.2d 1025 (5th Cir. 1980).

Jewel C. Rich v. Martin Marietta, 522 F.2d 333 (10th Cir. 1975).

Judge v. Marsh, 649 F. Supp. 770 (D.D.C. 1986).

Lam v. University of Hawai' 40 F.3d 1551 (9th Cir. 1994).

Logan v. St. Luke's Hospital Center, 428 F. Supp. 127 (S.D.N.Y 1977).

Love v. Alamance County Board of Education, 581 F. Supp. 1079 (M.D.N.C. 1984).

Matsushita Electric Industries Co., Ltd. v. Zenith Radio Corp., 475 U.S. 574 (1986).

Meritor Savings Bank v. Vinson, 477 U.S. 57 (1986).

Richardson v. Steak 'N Shake, Inc., 36,990 (E.D. Mo. 1987).

Rachel Kahn Best is a PhD candidate in sociology at the University of California, Berkeley. Her research uses quantitative methods to investigate the relationship between public institutions and inequality. Her dissertation tracks the emergence of disease interest groups in American politics and documents their effects on federal medical research priority setting.

Lauren B. Edelman is associate dean for the Department of Jurisprudence and Social Policy, Agnes Roddy Robb Professor of Law, and professor of sociology at the University of California, Berkeley. Her research focuses on how organizations both respond to and shape the meaning of law. She previously directed the Center for the Study of Law and Society at UC Berkeley and served as president of the Law and Society Association. She is currently writing a book titled Working Law: How Managers Transform Civil Rights in the American Workplace. 
Linda Hamilton Krieger is a professor of law at the University of Hawai' $i$ School of Law and a senior research fellow at the Center for the Study of Law and Society at the University of California, Berkeley. Her scholarly work centers on antidiscrimination law and policy and on judgment in legal decisionmaking. With Paul Brest, she is coauthor of Problem Solving and Decision Making: A Guide for Lawyers and Policy Makers (Oxford University Press, 2010).

Scott $\boldsymbol{R}$. Eliason is associate professor of sociology, faculty affliate of the BIO5 Institute, and member of the Statistics Program at the University of Arizona. He teaches and does research in the areas of inequality and stratification, causal inference, and categorical data modeling. 
